\title{
A SOCIAL AND PSYCHOLOGICAL STUDY OF I66 SPINAL CORD INJURED PATIENTS FROM QUEENSLAND
}

\author{
By Barbara Richards, Dip.Soc.Sc., A.I.M.S.W. \\ Spinal Injuries Unit, Princess Alexandra Hospital, Brisbane, Queensland, Australia
}

Abstract. A total of 166 patients supplied information on factors affecting their adjustment to their disability, including family relationships, accommodation, employment etc. Evaluation of this material was used to promote legislation to improve facilities for the disabled person in Queensland.

Key words: Spinal cord injuries; Social; Psychological.

REHABILITATION of people sustaining spinal cord injuries is unlikely to be successful unless the physical component is matched by a corresponding level of psychological adjustment. This paper sets out to discover what patients see as the important factors for re-integration into the community both socially and emotionally. In order to achieve a broad spectrum of views, I chose to follow up patients admitted to the Spinal Injuries Unit from Ist July I975 to 30th June I980.

Of the 362 consecutive patients admitted, I54 were excluded for the reasons shown in Table I.

TABLE I

Exclusions from study

\begin{tabular}{lr}
\hline Died & 48 \\
Substantially recovered & 92 \\
Transferred to Interstate Spinal Units & 7 \\
Untraceable & 7 \\
& \\
Total & I54 \\
\hline
\end{tabular}

A total of 208 patients were invited to complete a six page questionnaire which dealt with issues such as facilities for independent living, attitudes of society towards disabled people, sexuality, the affect of disability on the children of the family and the rights of disabled persons etc. One hundred and sixty-six replied in a most comprehensive way. Thirty-two failed to respond.

As a basis for the study patients were invited to list in order of priority a number of subjects shown in Table II.

\section{Accommodation}

This emerges, quite predictably, as the priority of most. Table III shows how housing problems have been dealt with. 
TABLE II

Priorities of 166 patients

\begin{tabular}{|c|c|c|c|}
\hline Service & Paraplegic (9I) & Tetraplegic (75) & Overall \\
\hline & $\%$ & $\%$ & $\%$ \\
\hline Accommodation & $59 \cdot 3$ & $58 \cdot 6$ & $59 \cdot 03$ \\
\hline Employment & 19.7 & $8 \cdot I$ & $15 \cdot 1$ \\
\hline Transport & $15 \cdot 3$ & $12 \cdot 0$ & $13 \cdot 8$ \\
\hline Equipment \& Assistance & 10.9 & $24 \cdot 0$ & $19 \cdot 2$ \\
\hline Financial \& Legal & $8 \cdot 9$ & $9 \cdot 3$ & 9.03 \\
\hline Sexuality & $7 \cdot 6$ & $I \cdot 3$ & $4 \cdot 8$ \\
\hline Leisure & $3 \cdot 2$ & $5 \cdot 6$ & $4 \cdot 4$ \\
\hline Sport & $7 \cdot 6$ & $\mathrm{I} \cdot 4$ & $3 \cdot 6$ \\
\hline
\end{tabular}

TABLE III

Housing arrangement

\begin{tabular}{lcc}
\hline Services used by I66 patients & \multicolumn{2}{c}{ Percentage of patients using each service } \\
\cline { 2 - 3 } & Paraplegic (9I) & Tetraplegic (75) \\
\hline & $\% \%$ & $\%$ \\
Moved or/Built new house & $38 \cdot 46$ & $37 \cdot 33$ \\
Extension & $5 \cdot 49$ & $5 \cdot 33$ \\
Adaptations & $67 \cdot 03$ & $64 \cdot 0$ \\
Queensland Housing Commission & $\mathrm{I} \cdot 09$ & $\mathrm{I} \cdot 33$ \\
Hostel & 0 & $4 \cdot 0$ \\
Nursing home/Hospital & 0 & $\mathrm{I0} \cdot 0$ \\
\hline
\end{tabular}

Many Queenslanders live in high-set houses necessitating moving or major alterations. In some cases patients moved and had adaptations done. Financial hardship was experienced by 80 per cent as a result.

Home visits are made by the hospital team to advise on adaptations up to a radius of 100 miles from the Unit and approximately 40 per cent of dwellings are altered prior to discharge. The majority of patients, however, prefer to be involved in the planning and supervision of modifications and wait until they return home.

Long-term accommodation for those unable to go home is very limited. There is one hostel in Brisbane for five severely disabled people and one house run by a voluntary organisation which can accommodate four to six people requiring minimal assistance. The alternative is placement in a nursing home where the young disabled person exists amongst an aged and often senile community. Nursing homes provide good physical care but are not suited to the needs and interests of the young. As suitable housing is one of the major factors in resettlement and as there are few choices in Queensland, I attempted, by giving a brief description of alternatives in the United Kingdom, to elicit what would be most acceptable if the opportunities were there. One hundred and forty replied to this question. Results suggest that most people would prefer to live within the community rather than in cluster groups of disabled people. (Table IV). 
TABLE IV

\begin{tabular}{lc}
\hline Services chosen by I40 patients & Percentage \\
& $\%$ \\
Adaptations with a grant from the Government & $89 \cdot 2$ \\
Attendant care scheme & $68 \cdot 5$ \\
Mobility/Barrier Free Housing & $55 \cdot 0$ \\
Hostels for 4-6 people with attendant care & $52 \cdot 14$ \\
Special Holiday accommodation & $40 \cdot 0$ \\
Cheshire Home with bungalow complex & $\mathrm{I} 7 \cdot 8$ \\
Blocks of purpose built flats with warden supervision & $\mathrm{I} 2 \cdot 8$ \\
Young disabled units of I0-50 residents & $7 \cdot 8$ \\
\hline
\end{tabular}

\section{Employment, Transport and Equipment}

As shown in Table II employment, transport and equipment were rated as second, third and fourth by paraplegics but not by tetraplegics who placed equipment and assistance as second priority. Return to employment is a significant feature of successful rehabilitation but is usually only possible if transport and suitable equipment is available. Table $\mathrm{V}$ shows the limitations experienced in return to work.

\section{TABLE V}

Employment

\begin{tabular}{lrccc}
\hline I6I Patients & \multicolumn{2}{c}{ Paraplegic } & \multicolumn{2}{c}{ Tetraplegic } \\
\cline { 2 - 5 } & Male & Female & Male & Female \\
\hline Employed & 2 I & 2 & IO & 2 \\
Students & 6 & 3 & 4 & I \\
Sheltered workshop & 2 & 0 & I & 0 \\
Industrial rehabilitation centre & 5 & 0 & 2 & I \\
Housewives & 0 & 4 & 0 & 3 \\
Retired & 5 & 0 & 3 & 0 \\
Unemployed & 32 & I I & 34 & 9 \\
Total & 7 I & 20 & 54 & I6 \\
\hline
\end{tabular}

Of the male paraplegics in open employment five returned to their own clerical jobs, two farmers with extra labour continued to manage their cane farms and the remaining 16 previously engaged in heavy manual work were absorbed into the labour force in various trades. Prior to injury most male tetraplegics had been occupied in outdoor work as jackaroos, stockmen on cattle stations, itinerant workers etc. Of the professional men, two returned to previously held jobs as teachers and one as a computer analyst. Fifty-three per cent remained unemployed for a variety of reasons often due to a combination of factors, as is shown in Table VI. 
TABLE VI

Reason for unemployment

\begin{tabular}{|c|c|c|c|c|}
\hline \multirow[t]{2}{*}{ Unemployed 86 patients $(53 \%)$} & \multicolumn{2}{|c|}{ Paraplegic } & \multicolumn{2}{|c|}{ Tetraplegic } \\
\hline & Male 32 & Female I I & Male 34 & Female 9 \\
\hline No suitable work & $\begin{array}{c}\% \\
7 \mathrm{I} \cdot 0\end{array}$ & $\begin{array}{c}\% \\
\text { I } 5.0\end{array}$ & $\begin{array}{c}\% \\
64.0\end{array}$ & $\begin{array}{c}\% \\
22 \cdot 0\end{array}$ \\
\hline No transport & $37 \cdot 0$ & $18 \cdot 0$ & $50 \cdot 0$ & $44 \cdot 0$ \\
\hline Rural area & $15 \cdot 6$ & 0.0 & $35 \cdot 2$ & 0.0 \\
\hline Medical reasons & $9 \cdot 2$ & I $8 \cdot 8$ & $26 \cdot 4$ & II $\cdot 0$ \\
\hline From choice & I $8 \cdot 7$ & $36 \cdot 3$ & $2 \cdot 9$ & $22 \cdot 2$ \\
\hline
\end{tabular}

\section{Financial and Legal}

Rated 5 th on the priority scale and consistently so by all participants. Sickness Benefit and Invalid Pension are the only two major Social Security Benefits and these are means tested per family and are very limited and thus disabled people often suffer considerable hardship. Awards for third party compensation in Queensland are usually lower than in other States and interim payments are rare.

\section{Sport and Leisure Activities}

In Queensland there is an infinite variety of sport and leisure activities available to everybody irrespective of class. It is not surprising, therefore, to learn that nearly all of the I66 patients had been engaged in outdoor pursuits prior to disablement. Thirty three per cent expressed frustration at being unable to pursue their favourite sport and had given up entirely. A number of tetraplegics were obviously experiencing difficulty in finding appropriate and satisfying outlets and felt isolated as a result.

\section{Attitudes and Relationships}

This section of the questionnaire invited participants to comment freely, in addition to answering on a yes/no basis. Uncertainty and fear following sudden disability is to be expected but can be dismissed if the patient is involved in his treatment, management, goal setting and decision-making from the outset. The question 'Were you satisfied with your rehabilitation programme?' produced a mixed response. Dissatisfaction was greatest amongst the tetraplegics who felt that there were insufficient facilities for them and that too often decisions were made for them not with them. However, overall, staff received high praise.

\section{Sexuality}

This was interestingly low in the order of priorities. Sexual counselling was a contentious issue. More specific information was requested on sexual capability, fertility and child bearing. The majority felt that this subject should be discussed in hospital with a follow-up service after discharge. 


\section{Adjustment to Disability and Community Attitudes}

Of the paraplegics, 53.5 per cent males and 35 per cent females claimed that they had adjusted in hospital whilst only 36.8 per cent male tetraplegics felt they had done so and one female tetraplegic over the age of 60 . The majority felt that adjustment was an on-going process which gets better with practice but is probably a lifetime job. There were those who made it quite clear that they hadn't as yet either adjusted or accepted and couldn't see themselves doing so.

A great deal of ambivalence was expressed over second-class citizenship and the reasons 'they, the disabled' felt or were made to feel this way. Anxieties were expressed particularly by men; and more so by tetraplegics than paraplegics and almost in the same ratio in the females.

Generally, previous friendships were maintained though established relationships were often put to the test. The young disabled groups experienced a problem where interests previously shared with their friends could no longer be indulged.

Few patients were concerned when children reacted to them as it was felt they were merely showing natural curiosity and interest. They were, however, perturbed by the number of adults who stared, pointed and turned away, shouted or showed other manifestations of rudeness. It was felt, however that most people were helpful when they were made aware of the implications of disability and most patients felt they were able to ask for and accept help when needed.

Only a few instances, mainly males from I5-20 year age-group showed a preference for associating with other disabled people. Nearly roo per cent expressed anger and frustration at the attitude of the State towards its' disabled population with regard to access, and finance particularly. It was felt that discrimination was due to ignorance rather than to a deliberate policy.

\section{Marital Status}

Permanent disability puts a great strain on any relationship. In some cases it is the disabled person who contributes largely to the breakdown of a partnership. Lack of or diminished sexual function appeared to be only a minor contributing factor to the disintegration of a marriage or more informal liaison. Out of 166 patients, only Is partnerships were dissolved.

\section{Effects of disability on children}

Only those whose parents were in the 25-40-year-old category appeared to have problems. Usually these were associated with teenagers who felt insecure. Truancy from school was the most common manifestation. Most children appeared to cope remarkably well.

\section{Follow-up}

Regrettably, for various reasons, there is no systematic social follow-up of patients discharged from the Spinal Injuries Unit at the present time. On request patients are referred when attending for check-ups. Periodic social reviews of patients would in many cases prevent readmission to hospital and avert other problems. Patients were overwhelmingly in favour of a follow-up service by the social worker. 


\section{Quality of Life}

Quality of life was summed up by 40 per cent as 'restricted but not at all bad'. Very few felt that life was not worth living whilst the rest were resigned basically to making the best of a bad lot.

\section{Conclusion}

There are certainly limitations attached to a study of this nature. The selection of non-factual material and the emphasis placed on it is always open to bias. It must be assumed that the yes/no answers are correct and the figures reliable although Disraeli said, 'There are three kinds of lies; lies, damn lies and statistics'. From the results, I have concluded that patients feel: that each disabled person has the right to decide on his/her own future and should be informed and offered assistance where necessary and that emphasis should be placed on the individual and not on the disability.

\section{SUMMARY}

The follow-up of I 66 patients discharged from the Brisbane Spinal Injuries Unit has shown that facilities for spinal cord injured patients in Queensland are inadequate. The size of Queensland adds to the problem. There would appear to be a real need for choices in accommodation, together with Care Attendant Schemes available when necessary. Appropriate training facilities and equal job opportunities for both sexes are required together with transport and essential equipment. Discrimination exists but mainly through ignorance or lack of communication. Within the Spinal Injuries Unit patients would like to see a total care plan with better facilities. The majority would also like to see care extended by periodic home visits following discharge. The study highlights the importance of the social and psychological aspects of spinal cord injury and the need for these two factors to be considered from the time of admission if successful resettlement is to be finally achieved.

Acknowledgements. I would like to thank Dr Bill Davies and Dr Vernon Hill without whose support and encouragement this paper would not have been written. My appreciation and gratitude must go also to those patients who contributed so much time and thought to the questionnaire.

\section{RÉSUMÉ}

Les soins à administrer aux I66 patients après avoir quitté le 'Brisbane Spinal Injuries Unit' (bloc des accidentés de la colonne vertébrale de l'hôpital à Brisbane) ont démontré que les facilités disponibles aux patients ayant eu le cordon médullaire endommagé, sont inadéquats au Queensland.

L'étendue du Queensland vient s'ajouter au problème. Il semblerait qu'un choix d'installations, de même qu'un système de soins à donner, quand ils sont nécessaires, ne sont pas adéquats. Des facilités d'entrainement approprié ainsi que l'opportunité de trouver un travail à conditions égales pour les deux sexes, sont nécessaires, de même que le sont les méthodes employées pour le transport des blessés et la nécessité d'avoir un appareillage essentiel. Le discernement entre les sexes existe, mais principalement dû à l'ignorance et au manque de communication.

Dans ce bloc où sont traités les blessés de la colonne vertébrale, les patients aimeraient voir un plan général et complet de soins à administrer, ainsi que de meilleures facilités. 
La majorité des patients aimerait également voir les soins prolongés par des visites périodiques à domicile, après avoir quitté l'hôpital. L'étude fait ressortir l'importance de l'aspect, à la fois social et psychologique qui s'applique au blessé de la colonne médullaire, et à la nécessité d'envisager ces deux facteurs à partir du moment de l'admission, si un rétablissement doit être finalement réalisé avec succès.

\section{ZUSAMMENFASSUNG}

Eine Überprüfung einhundertsechsundsechzig (I66) ehemaliger Patienten der Spinalen Klinik in Brisbane hat ergeben, das manche der Einrichtungen für die weitere Versorgung Querschnittsgelähmter unzulänglich sind.

Die grösse und ausdehnung des Staates Queensland verschlimmert dieses Problem. Ein echter Mangel besteht in der Auswahl der Unterkünfte gekuppelt mit Pflegemöglichkeit wo nötig. Passende Turnanlagen sowie ebenbürtige Berfusaussichten für beide Geschlechter sowie Transport und andere Hilfsmittel sind ein mangelnder Bedarf.

Discrimination existiert zwar, doch hauptsächlich verursacht durch unkenntniss der Tatsachen.

Patienten innerhalb der Klinik würden ein gesamtprogramm bevorzugen, welches eine Combination von Unterkunft mit Pflege, Transport und bessere Hilfsmittel einschliesst. Die Mehrheit dieser Gruppe hat auch den Wunsch geäussert, regelmässige Hausbesuche nach Klinischer entlassung einzuplanen.

Die Uberprüfung hat die Wichtigkeit der Soziologischen und Psychologischen Aspecte betont, welche bei Querschnittsgelähmten Patienten vom Zeitpunkt der Klinischen Aufnahme bis zur Rückkehr in das Gemeinschaftsleben unbedingt berücksichtigt wercen müssen, wenn dieses Ziel erreicht werden soll. 